\title{
Synthesis, Anti-Tumor Activity and Apoptosis-Inducing Effect of Novel Dimeric Keggin-Type Phosphotungstate
}

\author{
Yingxue Xue ${ }^{1}$, Yifei Yin ${ }^{1}, \mathrm{He} \mathrm{Li}^{2}$, Mingyu $\mathrm{Chi}^{1}$, Jiaxin Guo ${ }^{1}$, Guihua Cui ${ }^{1}$ and Wenliang $\mathrm{Li}^{1,3 *}$ \\ ${ }^{1}$ School of Pharmacy, Jilin Medical University, Jilin, China, ${ }^{2}$ Research and Development Department, NCPC Hebei Lexin \\ Pharmaceutical Co., Ltd., Hebei, China, ${ }^{3}$ Jilin Collaborative Innovation Center for Antibody Engineering, Jilin Medical University, \\ Jilin, China
}

OPEN ACCESS

Edited by:

Sanjun Shi,

Chengdu University of Traditional

Chinese Medicine, China

Reviewed by:

Shengnan $\mathrm{Li}$,

Hebei University of Technology, China

Lingyu Zhang,

Northeast Normal University, China

${ }^{*}$ Correspondence:

Wenliang Li

wenliang/@ciac.ac.cn

Specialty section:

This article was submitted to Pharmacology of Anti-Cancer Drugs,

a section of the journal

Frontiers in Pharmacology

Received: 24 November 2020

Accepted: 16 December 2020

Published: 27 January 2021

Citation:

Xue Y, Yin Y, Li H, Chi M, Guo J, Cui G and Li W (2021) Synthesis, Anti-Tumor Activity and Apoptosis-Inducing Effect of Novel Dimeric Keggin-

Type Phosphotungstate.

Front. Pharmacol. 11:632838.

doi: 10.3389/fphar.2020.632838
A dimeric Keggin-type phosphotungstate $(\mathrm{ODA})_{10}\left[\left(\mathrm{PW}_{11} \mathrm{FeO}_{39}\right)_{2} \mathrm{O}\right] \cdot 9 \mathrm{H}_{2} \mathrm{O}$ (abbreviated as $\mathrm{ODA}_{10}\left[\left(\mathrm{PW} \mathrm{F}_{11} \mathrm{Fe}\right)_{2}\right], \mathrm{ODA}=$ octadecyltrimethylammonium bromide) was synthesized and investigated comprehensively its antitumor activity on MCF-7 and A549 cells. The dimeric structure and amorphous morphology were characterized by FT-IR, UV-vis-DRS, SEM and $X R D$. The in vitro MTT assay of $\mathrm{ODA}_{10}\left[\left(\mathrm{PW}_{11} \mathrm{Fe}\right)_{2}\right]$ showed anticancer activity on MCF7 and $\mathrm{A} 549$ cells in a dose- and time-dependent manner, and the $\mathrm{IC}_{50}$ values for MCF-7 and A549 cells at $48 \mathrm{~h}$ were $5.83 \mu \mathrm{g} / \mathrm{ml}$ and $3.23 \mu \mathrm{g} / \mathrm{ml}$, respectively. The images of the $\mathrm{ODA}_{10}\left[\left(\mathrm{PW} \mathrm{W}_{11} \mathrm{Fe}\right)_{2}\right]$-treated cells observed by inverted biological microscope exhibited the characteristic morphology of apoptosis. Flow cytometric analysis showed cell apoptosis and cycle arrested at $\mathrm{S}$ phase induced by $\mathrm{ODA}_{10}\left[\left(\mathrm{PW}_{11} \mathrm{Fe}\right)_{2}\right]$. The above results illuminated the main mechanism of the antitumor action of $\mathrm{ODA}_{10}\left[\left(\mathrm{PW} \mathrm{P}_{11} \mathrm{Fe}\right)_{2}\right]$ on MCF-7 and A549 cells, indicating that this dimeric phosphotungstate is a promising anticancer drug.

Keywords: anti-tumor, apoptosis, dimeric, Keggin-type, phosphotungstate

\section{INTRODUCTION}

With the increasing morbidity and mortality, cancer has become a major killer that leads to healthand life-threatening for humans all over the world (Sun et al., 2019). At present, the main methods for the treatment of cancer are surgery, drug therapy, radiation therapy and cryotherapy. Among them, chemotherapy is also an effective method for cancer treatment (Xiao et al., 2019; Chen et al., 2020; Liu et al., 2020). Many chemotherapeutic agents, such as cisplatin (Weiss and Christian, 1993; Chen et al., 2018), fluorouracil (Arkenau et al., 2003) and capecitabine (Ssif et al., 2008), etc., have shown the potential for alleviating symptoms and curing the cancer (Cao et al., 2020; Geraldi, 2020; Zhao et al., 2020). However, most chemotherapeutic drugs possess inherent disadvantages, such as poor selectivity, severe side effect, low efficiency and drug resistance in cancer cells (Carr et al., 2008; Jonckheere et al., 2014; Hamis et al., 2018). Therefore, it is necessary to design drugs with high efficiency and low toxicity.

Polyoxometalates (abbreviated as POMs) are a series of transition metal oxygen anion clusters, which are mainly composed of molybdenum $\left(\mathrm{Mo}^{\mathrm{VI}}\right)$, tungsten $\left(\mathrm{W}^{\mathrm{Vl}}\right)$, vanadium $\left(\mathrm{V}^{\mathrm{V}}\right)$, niobium $\left(\mathrm{Nd}^{\mathrm{V}}\right)$, and tantalum $\left(\mathrm{Ta}^{\mathrm{V}}\right)$ in their highest oxidation state bridged by oxygen atoms (Rhule et al., 1998; Wang et al., 2003). Intriguingly, many other elements can be incorporated into the framework of POMs, leading to the diversity in structures and properties (Dianat et al., 2015), such as redox potential, polarity, thermal stability and electronic properties, etc., making them attractive for 
application in the fields of catalysis (Mizuno et al., 2005; Hill, 2007), electrochemistry (Goura et al., 2020), material science (Du et al., 2010) and medicine (Muller et al., 1998). Jasmin et al. (1974) firstly reported the antivirus activity of $\left(\mathrm{NH}_{4}\right)_{17} \mathrm{Na}$ $\left[\mathrm{NaSb}_{9} \mathrm{~W}_{21} \mathrm{O}_{86}\right]$ (HPA-23) against sarcoma virus. Since then, more POMs have been found to exhibit antitumor (Boulmier et al., 2017; Bijelic et al., 2019), antibacterial (Ma et al., 2020), antivirus (Qi et al., 2013), and antidiabetic activities (Liu W. J. et al., 2016). It is reported that POMs are significant antitumor drug candidates with high efficiency and low toxicity for curing most types of cancers, such as pancreatic cancer, breast cancer, leukemia, colon cancer, ovarian cancer and so on (Li et al., 2017; Hu et al., 2019).

The unique advantage of POMs over current drugs lies in the fact that the molecular structure and physiochemical properties of POMs are tunable and can be easily synthesized from readily available precursors in a few synthetic steps (Judd et al., 2001; Müller et al., 2006). POMs can be surface modified with synthetic organic compounds or natural molecules to effectively improve the biological activity in vitro and/or in vivo (Sun et al., 2016; Van Rompuy and Parac-Vogt, 2019). Electrostatic interaction, as a method of surface modification of POMs, combining organic countercations (such as quaternary ammonium salts) with POMs anions together, which makes the formed POMs take advantage of the synergistic effect and enhance the antitumor activity ( $\mathrm{Yu}$ et al., 2014; Qu et al., 2017; Cheng et al., 2018). Quaternary ammonium salts are widely used as an antibacterial agent against a variety of bacteria, fungi and virus (Diz et al., 2001), which is based on the diversity in properties of low-molecular weight, outstanding cell membrane penetration, extended residence time, low toxicity, good biological activity and environmental stability (Dizman et al., 2006).

On the other hand, Keggin-type POMs were gaining increased interest as antitumor and antivirus agents due to the simple structure, small size and being easily synthesized (Shigeta et al., 2003; Zheng et al., 2009; Liu X. et al., 2016), such as $\mathrm{K}_{6} \mathrm{H}\left[\mathrm{CoW}_{11} \mathrm{O}_{39} \mathrm{CpM}\right] \cdot \mathrm{nH}_{2} \mathrm{O}\left(\mathrm{M}=\mathrm{Zr}, \mathrm{Ti}, \mathrm{Fe}, \mathrm{Cp}=\eta^{5}-\mathrm{C}_{5} \mathrm{H}_{5}\right)$, $\mathrm{Ag}_{3}\left[\mathrm{PW}_{12} \mathrm{O}_{40}\right], \quad \mathrm{Ag}_{6}\left[\mathrm{SiW}_{10} \mathrm{~V}_{2} \mathrm{O}_{40}\right]$ and $\mathrm{Ag}_{4}\left[\mathrm{SiW}_{12} \mathrm{O}_{40}\right]$, all exhibiting inhibitory effect on tumor cells and sporotrichosis (Dianat et al., 2013; Mathias et al., 2020), respectively. But the work involving both the synthesis and antitumor effect of dimeric Keggin-type POMs are seldomly reported. Although the synthesis of dimeric $\left[\mathrm{N}\left(\mathrm{CH}_{3}\right)_{4}\right]_{10}\left[\left(\mathrm{PW}_{11} \mathrm{FeO}_{39}\right)_{2} \mathrm{O}\right] \cdot 12 \mathrm{H}_{2} \mathrm{O}$ (Pichon et al., 2008) and $[\mathrm{Bmim}]_{10}\left[\left(\mathrm{PW}_{11} \mathrm{FeO}_{39}\right)_{2} \mathrm{O}\right] \cdot 0.5 \mathrm{H}_{2} \mathrm{O}$ (Santos et al., 2012) were reported, the further studies on the antitumor efficacy and mechanism of dimeric Keggin-type phosphotungstate with quaternary ammonium cation are not very frequent.

The exact mechanism of cancer cells death induced by POMs is still unknown, but it is reported that the antitumor activity of POMs correlates with their biological activities, including immunomodulatory (Sun et al., 2010), apoptotic (Cao et al., 2017) and inhibition effects toward enzymes (Prudent et al., 2008). Due to the lack of a comprehensive research on the biological mechanism of POMs, compared to much more common organic drugs, POMs as inorganic drugs are still rarely applied in pharmacy field (Guo and Sadler, 1999). So, considerable attention has been paid to the cellular and molecular mechanisms between tumor cells and POMs.

In the present work, we have chosen the quaternary ammonium salt with relatively long alkyl chain of octadecyltrimethylammonium bromide (ODAB) as organic counteraction, which is expected to exhibit better biocompatibility and higher cell membrane penetration, because the biological activity of quaternary ammonium salts correlates with their molecular structure and the length of the carbon chain. The longer alkyl chain of the compounds contributes to higher antibacterial activity of theirs (Abel et al., 2002). Herein, it is firstly reported that a dimeric Keggin-type polyoxometalate (ODA $)_{10}\left[\left(\mathrm{PW}_{11} \mathrm{FeO}_{39}\right)_{2} \mathrm{O}\right] \cdot 9 \mathrm{H}_{2} \mathrm{O}$ $\left(\mathrm{ODA}_{10}\left[\left(\mathrm{PW}_{11} \mathrm{Fe}\right)_{2}\right]\right)$ was synthesized based on electrostatic interaction between octadecyltrimethylammonium cation and $\left[\left(\mathrm{PW}_{11} \mathrm{FeO}_{39}\right)_{2} \mathrm{O}\right]^{10-}$ anion. The structure and morphological feature of $\mathrm{ODA}_{10}\left[\left(\mathrm{PW}_{11} \mathrm{Fe}\right)_{2}\right]$ were characterized. The in vitro antitumor activity of $\mathrm{ODA}_{10}\left[\left(\mathrm{PW}_{11} \mathrm{Fe}\right)_{2}\right]$ on MCF-7 and A549 cells was investigated. And the morphological changes and cell density of MCF-7 and A549 cells induced by $\mathrm{ODA}_{10}\left[\left(\mathrm{PW}_{11} \mathrm{Fe}\right)_{2}\right]$ were detected by inverted biological microscopy. Furthermore, cell apoptosis and cell cycle distribution were analyzed.

\section{MATERIALS AND METHODS}

\section{Materials}

Sodium tungstate dihydrate $\left(\mathrm{Na}_{2} \mathrm{WO}_{4} \cdot 2 \mathrm{H}_{2} \mathrm{O}\right)$, Sodium phosphate dibasic $\left(\mathrm{Na}_{2} \mathrm{HPO}_{4}\right)$, Iron nitrate nonahydrate $\left(\mathrm{Fe}\left(\mathrm{NO}_{3}\right)_{3} \cdot{ }^{9} \mathrm{H}_{2} \mathrm{O}\right)$, Sodium bicarbonate $\left(\mathrm{NaHCO}_{3}\right)$ and octadecyltrimethylammonium bromide (ODAB) were acquired from Sinopharm Chemical Reagent Co. Ltd., China. Cisplatin and carboplatin were purchased from Nanjing Jingzhu Bio-technology Co., Ltd. (Nanjing, China). Trypsin, phosphate buffer saline (PBS), dimethyl sulfoxide (DMSO) and 3-[4,5-dimethylthiazol-2-yl]-2,5-diphenyltetrazolium bromide (MTT) were obtained from Sigma (St. Louis, MO, United States). Fetal bovine serum (FBS), RPMI-1640 Medium and penicillin-streptomycin were purchased from Gibco BRL (Grand Island, NY, United States). Annexin V-FITC apoptosis detection kit and cell cycle kit were obtained from BD Biosciences (San Jose, CA, United States). All chemicals and solvents were used as received from commercial sources without further purification. (TEA $)_{10}\left[\left(\mathrm{PW}_{11} \mathrm{FeO}_{39}\right)_{2} \mathrm{O}\right] \cdot 3 \mathrm{H}_{2} \mathrm{O}$ and (TMA $)_{10}\left[\left(\mathrm{PW}_{11} \mathrm{FeO}_{39}\right)_{2} \mathrm{O}\right]$. $4 \mathrm{H}_{2} \mathrm{O}$ (TEA = tetraethyl ammonium bromide, TMA = tetramethyl ammonium bromide) were prepared according to the literature (Pichon et al., 2008), and the characteristic data were consistent with previously published values (Pichon et al., 2008; Santos et al., 2012).

\section{General Measurements}

The content of $\mathrm{P}, \mathrm{W}, \mathrm{Fe}$ in the phosphotungstate was performed on an ICP-OES Plasma Spec (Thermo iCAP 6000), and the elemental analysis of $\mathrm{C}, \mathrm{H}, \mathrm{N}$ was tested on a $\mathrm{CHN}$ elemental analyzer (Perkin-Elmer 2400). Thermogravimetric analysis (TGA) was measured on a Shimadzu DTG-60 instrument using $\mathrm{N}_{2}$, with a heating rate of $6^{\circ} \mathrm{C} \mathrm{min}^{-1}$. Fourier Transform 
infrared (FT-IR) spectroscopy was tested by Nicolet-Impact 400 spectrometer using $\mathrm{KBr}$ disk. The UV-vis diffuse reflectance spectra (UV-vis DRS) were performed on a UV-Vis-NIR spectrometer (Agilent Technologies Cary Series) using $\mathrm{BaSO}_{4}$ as reference. X-ray diffraction (XRD) data were tested by a SHIMADZU XRD-6000 X-ray diffractometer with $\mathrm{Cu} \mathrm{Ka}$ radiation $(\lambda=0.1548 \mathrm{~nm})$. The morphology of the phosphotungstate was analyzed by scanning electron microscope (SEM) performed on a JSM-6360LV microscope. Particle size distribution was obtained by dynamic light scattering (DLS) using a Mastersizer 2000 laser particle size analyzer.

\section{Synthesis of (ODA $)_{10}\left[\left(\mathrm{PW}_{11} \mathrm{FeO}_{39}\right)_{2} \mathrm{O}\right] \cdot 9 \mathrm{H}_{2} \mathrm{O}$ $\left(\mathrm{ODA}_{10}\left[\left(\mathrm{PW}_{11} \mathrm{Fe}\right)_{2}\right]\right)$}

$\mathrm{Na}_{2} \mathrm{WO}_{4} \cdot 2 \mathrm{H}_{2} \mathrm{O}(3.3 \mathrm{~g})$ was dissolved in $20 \mathrm{ml}$ of distilled $\mathrm{H}_{2} \mathrm{O}$ in a flask. Then $\mathrm{Na}_{2} \mathrm{HPO}_{4}$ powder $(0.13 \mathrm{~g})$ was added to the solution in a molar proportion $\left(\mathrm{Na}_{2} \mathrm{WO}_{4} \cdot 2 \mathrm{H}_{2} \mathrm{O}: \mathrm{Na}_{2} \mathrm{HPO}_{4}\right)$ of $11: 1$. After $1 \mathrm{~h}$ of stirring at $80-90^{\circ} \mathrm{C}$, conc. $\mathrm{HNO}_{3}$ was added drop by drop to make the $\mathrm{pH}$ of the solution be 4.8 . Then, $\mathrm{Fe}\left(\mathrm{NO}_{3}\right)_{3} \cdot 9 \mathrm{H}_{2} \mathrm{O}(0.49 \mathrm{~g}, 1.2 \mathrm{mmol})$ was added and the $\mathrm{pH}$ was adjusted to 4.5 by adding $\mathrm{NaHCO}_{3}(1 \mathrm{M})$ drop by drop. $1.8 \mathrm{~g}$ of octadecyltrimethylammonium bromide (ODAB) was added, causing yellow precipitates produced, which were then filtrated, washed twice with distilled water and dried under vacuum. Anal. (\%): calcd for (ODA $)_{10}\left[\left(\mathrm{PW}_{11} \mathrm{FeO}_{39}\right)_{2} \mathrm{O}\right] \cdot 9 \mathrm{H}_{2} \mathrm{O}$ : $\mathrm{P}, 0.71 ; \mathrm{W}, 46.14 ; \mathrm{Fe}, 1.28 ; \mathrm{C}, 28.76 ; \mathrm{H}, 5.45 ; \mathrm{N}, 1.60 ; \mathrm{H}_{2} \mathrm{O}, 1.85$; found: P, 0.78; W, 48.16; Fe, 1.33; C, 29.21; H, 5.49; N, 1.65; $\mathrm{H}_{2} \mathrm{O}, 1.91$.

\section{Cell Lines and Cell Culture Conditions}

Human breast cancer cells MCF-7 and human non-small cell lung cancer cells A549 (ATCC) were incubated in RPMI 1640 medium with penicillin $(100 \mathrm{U} / \mathrm{ml})$, streptomycin $(100 \mu \mathrm{g} / \mathrm{ml})$ and $\mathrm{FBS}(10 \%)$ at $37^{\circ} \mathrm{C}$ with $5 \% \mathrm{CO}_{2}$ in an incubator.

\section{Cell Viability Studies}

The anti-proliferation effect of the phosphotungstate was detected by the MTT assay. The stock solution of $\mathrm{ODA}_{10}$ $\left[\left(\mathrm{PW}_{11} \mathrm{Fe}\right)_{2}\right]$ with the concentration of $1 \mathrm{mg} / \mathrm{ml}$ was prepared in DMSO, and then sterilized by the methyl cellulose ester filter membrane with pore size $0.22 \mu \mathrm{m}$. At last, the stock solution was diluted by RPMI 1640 under sterile condition.

Cells were seeded into a 96-well plate at a density of $1 \times 10^{4}$ cells/well. $100 \mu \mathrm{l} /$ well of RPMI 1640 medium was added to each well to incubate the cells for $24 \mathrm{~h}$, and then the medium was replaced by various concentrations of $\mathrm{ODA}_{10}\left[\left(\mathrm{PW}_{11} \mathrm{Fe}\right)_{2}\right]$ $(1,3,6,12,24 \mu \mathrm{g} / \mathrm{ml})$. Each concentration has four duplicate samples. After $6,12,24$ and $48 \mathrm{~h}, 20 \mu \mathrm{l}$ of MTT $(5 \mathrm{mg} / \mathrm{ml})$ was added to each well, and then the plate continued to be incubated for $4 \mathrm{~h}$ in the incubator. Next, the formed formazan crystals were dissolved in $150 \mu \mathrm{l}$ DMSO after removing the MTT medium. Finally, the absorbance was measured at a wavelength of $490 \mathrm{~nm}$ by an automatic microplate reader.

\section{Morphological Observation}

To observe whether the density and morphology of the tumor cells induced by the phosphotungstate changed or not, cells were seeded into a 6-well plate at a density of $2 \times 10^{5}$ cells/well for $24 \mathrm{~h}$ at $37^{\circ} \mathrm{C}$, and then treated with different concentration of $\mathrm{ODA}_{10}$ $\left[\left(\mathrm{PW}_{11} \mathrm{Fe}\right)_{2}\right](1-24 \mu \mathrm{g} / \mathrm{ml})$. After $24 \mathrm{~h}$, the cellular density and morphology were observed by the inverted biological microscopy (XDS1C, Shanghai Wanheng Precision Instrument Co. Ltd., China).

\section{Flow Cytometry Analysis of Cell Apoptosis}

Cells were seeded into a six-well plate $\left(2 \times 10^{5}\right.$ cells/well $)$ for $24 \mathrm{~h}$, and then exposed to different concentration of $\mathrm{ODA}_{10}$ $\left[\left(\mathrm{PW}_{11} \mathrm{Fe}\right)_{2}\right](1-24 \mu \mathrm{g} / \mathrm{ml})$. After $24 \mathrm{~h}$, the cells were collected, washed thrice with cold PBS and then centrifugated. After discarding the supernatant, the cells were resuspended in Annexin-V-FITC/PI solution and remained in the dark for $15 \mathrm{~min}$ at room temperature. The cell apoptosis was determined on a FAC Scanto ${ }^{\mathrm{TM}}$ flow cytometer (Becton Dickinson, United States).

\section{Flow Cytometry Analysis of Cell Cycle Distribution}

Cells were seeded into a six-well plate $\left(10^{6}\right.$ cells/well $)$ for $24 \mathrm{~h}$ at $37^{\circ} \mathrm{C}$, and then exposed to different concentration of $\mathrm{ODA}_{10}$ $\left[\left(\mathrm{PW}_{11} \mathrm{Fe}\right)_{2}\right](1-24 \mu \mathrm{g} / \mathrm{ml})$. After $24 \mathrm{~h}$, the cells were collected using trypsin, centrifugated and then washed with PBS for two times. After being fixed by ice-cold $70 \%$ ethanol at $4^{\circ} \mathrm{C}$ overnight, the cells continued to be washed with cold PBS and resuspended in propidium iodide (PI) staining solution in the dark at $37^{\circ} \mathrm{C}$ for 30 min. Finally, the cell cycle was determined on a FAC Scanto ${ }^{\mathrm{TM}}$ flow cytometer (Becton Dickinson, United States).

\section{RESULTS AND DISCUSSION}

\section{Synthesis and Characterization of the Dimeric Keggin-Type Phosphotungstate}

The adjustment of $\mathrm{pH}$ is vital to the synthesis of the dimeric oxobridged $\left[\left(\mathrm{PW}_{11} \mathrm{FeO}_{39}\right)_{2} \mathrm{O}\right]^{10-}$ anion, which usually exists at $\mathrm{pH}=$ 3-5 (Liu K. et al., 2016). The dimeric phosphotungstate $\mathrm{ODA}_{10}$ $\left[\left(\mathrm{PW}_{11} \mathrm{Fe}\right)_{2}\right]$ consists of two phosphotungstate units $\mathrm{PW}_{11} \mathrm{Fe}^{\text {III }} \mathrm{O}_{39}$ which are linked by $\mathrm{Fe}-\mathrm{O}-\mathrm{Fe}$ bond, the structure is shown in Figure 1A.

FT-IR spectra provided clear evidence for the successful preparation of the dimeric Keggin-type phosphotungstate $\mathrm{ODA}_{10}\left[\left(\mathrm{PW}_{11} \mathrm{Fe}\right)_{2}\right]$ (Figure 1B). IR spectrum of $\mathrm{ODA}_{10}$ $\left[\left(\mathrm{PW}_{11} \mathrm{Fe}\right)_{2}\right]$ showed characteristic peaks of Keggin-type polyoxometalates (Kuznetsova et al., 1996), which appeared at $1,092,1,056,951,881,815 \mathrm{~cm}^{-1}$. The peaks at $1,092,1,056 \mathrm{~cm}^{-1}$ were assigned to asymmetric $\mathrm{P}-\mathrm{O}_{\mathrm{a}}$ stretching band. The peak at $951 \mathrm{~cm}^{-1}$ corresponded to $v_{\mathrm{as}}\left(\mathrm{W}=\mathrm{O}_{\mathrm{d}}\right)$ vibration. The peaks attributed to $v_{\mathrm{as}}\left(\mathrm{W}-\mathrm{O}_{\mathrm{b}}-\mathrm{W}\right)$ and $v_{\mathrm{as}}\left(\mathrm{W}-\mathrm{O}_{\mathrm{c}}-\mathrm{W}\right)$ vibrations appeared at 881 and $815 \mathrm{~cm}^{-1}$, respectively. In addition, the asymmetric $\mathrm{Fe}-\mathrm{O}-\mathrm{Fe}$ stretching vibration of dimeric phosphotungstates was observed at $750 \mathrm{~cm}^{-1}$ with a shoulder 

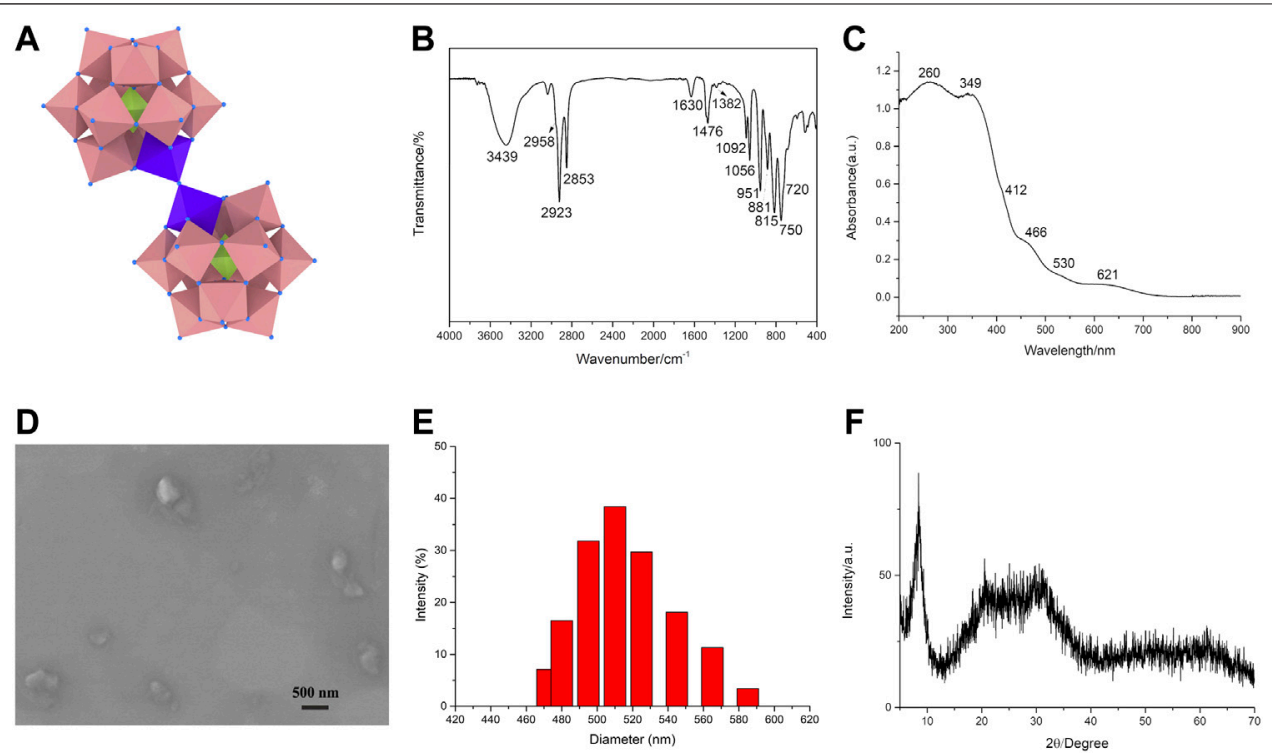

FIGURE 1 | The structure and characterization of the dimeric Keggin-type phosphotungstate. The structure of $\mathrm{ODA}_{10}\left[\left(\mathrm{PW} \mathrm{W}_{11} \mathrm{Fe}\right)_{2}\right]$ (A). IR spectrum (B), UV-vis DRS (C), SEM image (D), DLS characterization (E), and XRD pattern (F) of $\mathrm{ODA}_{10}\left[\left(\mathrm{PW}_{11} \mathrm{Fe}\right)_{2}\right]$.

around $720 \mathrm{~cm}^{-1}$ (Kuznetsova et al., 1996; Kuznetsova et al., 1997), which illuminated the dimeric structure of $\mathrm{ODA}_{10}$ $\left[\left(\mathrm{PW}_{11} \mathrm{Fe}\right)_{2}\right]$. The IR peaks ascribed to the $-\mathrm{CH}_{2}$ asymmetric and symmetric stretching bands appeared at 2,923 and $2,853 \mathrm{~cm}^{-1}$, showing the existence of quaternary ammonium in $\mathrm{ODA}_{10}\left[\left(\mathrm{PW}_{11} \mathrm{Fe}\right)_{2}\right]$. The bands attributed to the $-\mathrm{CH}_{3}$ asymmetric stretching and scissoring modes were observed at 2,958 and $1,382 \mathrm{~cm}^{-1}$, respectively. The peak at $1,476 \mathrm{~cm}^{-1}$ was due to the $-\mathrm{CH}_{2}$ scissoring modes (Myrzakozha et al., 1999a; Myrzakozha et al., 1999b). The characteristic peaks of water were observed at 3,439 and $1,630 \mathrm{~cm}^{-1}$. The above results illuminated that $\mathrm{ODA}_{10}\left[\left(\mathrm{PW}_{11} \mathrm{Fe}\right)_{2}\right]$ was of dimeric Keggintype structure and prepared by electrostatic interaction between quaternary ammonium cations and heteropoly anions.

$\mathrm{UV}$-vis DRS of the dimeric $\mathrm{ODA}_{10}\left[\left(\mathrm{PW}_{11} \mathrm{Fe}\right)_{2}\right]$ is shown in Figure 1C. The absorption at $260 \mathrm{~nm}$ was due to $\mathrm{O} \rightarrow \mathrm{W}$ charge transfer transition. The bands at $349 \mathrm{~nm}$ and $412 \mathrm{~nm}$ corresponded to $\mathrm{O} \rightarrow \mathrm{Fe}$ charge transfer transition of oxo-bridged di-iron complexes (Kurtz, 1990). Another evidence of Fe-O-Fe bond presented the characteristic absorptions at 466, 530 and $621 \mathrm{~nm}$ which were attributed to $\mathrm{O} \rightarrow \mathrm{Fe}$ charge transfer transitions (Kurtz, 1990). So, the IR and UV-vis DRS results all indicated that ODA 10 $\left[\left(\mathrm{PW}_{11} \mathrm{Fe}\right)_{2}\right]$ possessed dimeric structure.

The SEM image of the dimeric $\mathrm{ODA}_{10}\left[\left(\mathrm{PW}_{11} \mathrm{Fe}\right)_{2}\right]$ is shown in Figure 1D. The particles of $\mathrm{ODA}_{10}\left[\left(\mathrm{PW}_{11} \mathrm{Fe}\right)_{2}\right]$ were slightly irregular in shape and the particle size was about $510 \mathrm{~nm}$ measured by DLS (Figure 1E), which was consistent with the result of SEM image. The obtained particles showed amorphous morphology, which might be caused by the relatively long carbon chain of organic countercations, making no crystalline feature observed in $\mathrm{ODA}_{10}\left[\left(\mathrm{PW}_{11} \mathrm{Fe}\right)_{2}\right]$, which was also proved by the results of
XRD pattern of ODA $10\left[\left(\mathrm{PW}_{11} \mathrm{Fe}\right)_{2}\right]$ (Figure 1F). The spectrum recorded for $\mathrm{ODA}_{10}\left[\left(\mathrm{PW}_{11} \mathrm{Fe}\right)_{2}\right]$ indicated an amorphous feature due to the lack of crystallinity caused by ODAB, which had strong diffraction peaks at the $2 \theta$ degree of $6.9^{\circ}-10.3^{\circ}$ and a weak broad peak at $14.3^{\circ}-39.2^{\circ}$. The characteristic diffractions of Keggin-type polyoxometalate were detected at $8.28^{\circ}, 8.9^{\circ}, 9.1^{\circ}, 27.9^{\circ}$ and $28.9^{\circ}$, etc (Jalil et al., 2003), so it is concluded that $\mathrm{ODA}_{10}\left[\left(\mathrm{PW}_{11} \mathrm{Fe}\right)_{2}\right]$ was of Keggin-type structure. The broad peak at $14.3^{\circ}-39.2^{\circ}$ manifested again that the poor crystallinity of $\mathrm{ODA}_{10}$ $\left[\left(\mathrm{PW}_{11} \mathrm{Fe}\right)_{2}\right]$ resulted from the longer carbon chain of quaternary ammonium cations. The above results of SEM and XRD proved that the dimeric $\mathrm{ODA}_{10}\left[\left(\mathrm{PW}_{11} \mathrm{Fe}\right)_{2}\right]$ had amorphous morphology and contained Keggin-type structure after quaternary ammonium cations combining with heteropoly anions.

\section{Anticancer Activity Studies}

The in vitro anti-proliferation activity of $\mathrm{ODA}_{10}\left[\left(\mathrm{PW}_{11} \mathrm{Fe}\right)_{2}\right]$ on MCF-7 and A549 cells was evaluated by the MTT assay. Cells were exposed to different concentrations of $\mathrm{ODA}_{10}$ $\left[\left(\mathrm{PW}_{11} \mathrm{Fe}\right)_{2}\right](1,3,6,12,24 \mu \mathrm{g} / \mathrm{ml})$ for $6,12,24$ and $48 \mathrm{~h}$. As shown in Figures $2 A, B$, the cell viability decreased with the concentration of $\mathrm{ODA}_{10}\left[\left(\mathrm{PW}_{11} \mathrm{Fe}\right)_{2}\right]$ increasing, which illuminated that the anti-proliferative effects of $\mathrm{ODA}_{10}$ $\left[\left(\mathrm{PW}_{11} \mathrm{Fe}\right)_{2}\right]$ depended on its concentration. For MCF-7 cells, after treatment with $\mathrm{ODA}_{10}\left[\left(\mathrm{PW}_{11} \mathrm{Fe}\right)_{2}\right]$, the cell viability declined to 76.4 at $6,52.1$ at $12,36.9$ at 24 and $14.2 \%$ at $48 \mathrm{~h}$. Analogously, for A549 cells, the cell viability was $70.7,56.8,26.3$ and $4.7 \%$ at $6,12,24$ and $48 \mathrm{~h}$, respectively. The above results indicated that $\mathrm{ODA}_{10}\left[\left(\mathrm{PW}_{11} \mathrm{Fe}\right)_{2}\right]$ exhibited inhibitory activity against tumor cells growth in a time- 

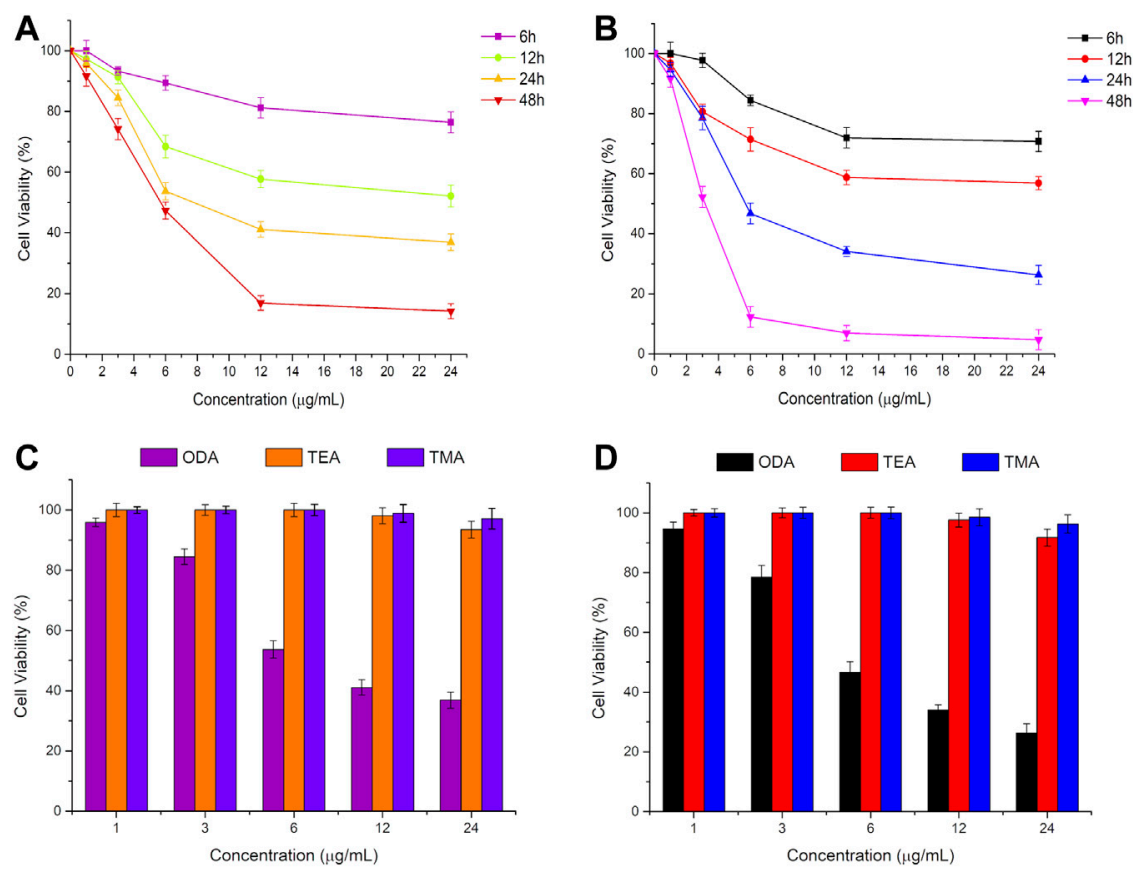

FIGURE 2 In vitro cytotoxicity profiles of $\mathrm{ODA}_{10}\left[\left(\mathrm{PW}_{11} \mathrm{Fe}\right)_{2}\right]$ on $\mathrm{MCF}-7$ cells $\mathbf{( A )}$ and $\mathrm{A} 549$ cells (B) for $6,12,24$ and $48 \mathrm{~h}$, and different phosphotungstates on $\mathrm{MCF}$ 7 cells (C) and $\mathrm{A} 549$ cells (D) for $24 \mathrm{~h}$ by MTT at different doses. (ODA: ODA 10 [(PW $\left.\left.{ }_{11} \mathrm{Fe}\right)_{2}\right]$; TEA: $(\mathrm{TEA})_{10}\left[\left(\mathrm{PW}_{11} \mathrm{FeO}_{39}\right)_{2} \mathrm{O}\right] \cdot 3 \mathrm{H}_{2} \mathrm{O} ; \mathrm{TMA}\left(\mathrm{TMA}_{10}\left[\left(\mathrm{PW} \mathrm{H}_{11} \mathrm{FeO}{ }_{39}\right)_{2} \mathrm{O}\right] \cdot 4 \mathrm{H}_{2} \mathrm{O}\right)$.

TABLE $1 \mid I C_{50}$ and $I C_{25}$ values of $\mathrm{ODA}_{10}\left[\left(\mathrm{PW}_{11} \mathrm{Fe}\right)_{2}\right]$ against MCF-7 and A549 cells.

\begin{tabular}{|c|c|c|c|c|c|c|c|c|}
\hline \multirow[t]{2}{*}{ Cell line } & \multicolumn{4}{|c|}{$\mathrm{IC}_{50}(\mu \mathrm{g} / \mathrm{ml})$} & \multicolumn{4}{|c|}{$\mathrm{IC}_{25}(\mu \mathrm{g} / \mathrm{ml})$} \\
\hline & $6 \mathrm{~h}$ & $12 \mathrm{~h}$ & $24 \mathrm{~h}$ & $48 h$ & $6 \mathrm{~h}$ & $12 \mathrm{~h}$ & $24 \mathrm{~h}$ & $48 h$ \\
\hline MCF-7 & - & - & 8.02 & 5.83 & 29.28 & 5.05 & 4.13 & 2.78 \\
\hline A549 & - & - & 5.75 & 3.23 & 10.68 & 4.71 & 3.35 & 1.92 \\
\hline
\end{tabular}

dependent effect during these periods. $\mathrm{IC}_{50}$ values of $\mathrm{ODA}_{10}$ $\left[\left(\mathrm{PW}_{11} \mathrm{Fe}\right)_{2}\right]$ against MCF-7 and A549 cells at different time were presented in Table 1 . The calculated $\mathrm{IC}_{50}$ values in MCF7 cells for 24 and $48 \mathrm{~h}$ were $8.02 \mu \mathrm{g} / \mathrm{ml}$ and $5.83 \mu \mathrm{g} / \mathrm{ml}$, respectively, and for $\mathrm{A} 549$ cells, the $\mathrm{IC}_{50}$ value was observed to be $5.75 \mu \mathrm{g} / \mathrm{ml}$ at $24 \mathrm{~h}$ and $3.23 \mu \mathrm{g} / \mathrm{ml}$ at $48 \mathrm{~h}$. For the short treatment time groups, $6 \mathrm{~h}$ and $12 \mathrm{~h}$, of MCF-7 and A549 cells, the inhibition rate was lower than $50 \%$, thus $\mathrm{IC}_{50}$ values in MCF-7 and A549 cells for $6 \mathrm{~h}$ and $12 \mathrm{~h}$ were not obtained in Table 1. Nevertheless, $\mathrm{IC}_{25}$ values of $\mathrm{ODA}_{10}\left[\left(\mathrm{PW}_{11} \mathrm{Fe}\right)_{2}\right]$ against MCF-7 and A549 cells at different times were calculated and shown in Table 1. For MCF-7 cells, $\mathrm{IC}_{25}$ values were $29.28 \mu \mathrm{g} / \mathrm{ml}, 5.05 \mu \mathrm{g} / \mathrm{ml}, 4.13 \mu \mathrm{g} / \mathrm{ml}$ and $2.78 \mu \mathrm{g} /$ $\mathrm{ml}$ at $6,12,24$ and $48 \mathrm{~h}$, respectively, and $\mathrm{IC}_{25}$ values in $\mathrm{A} 549$ cells for $6,12,24$ and $48 \mathrm{~h}$ were $10.68 \mu \mathrm{g} / \mathrm{ml}, 4.71 \mu \mathrm{g} / \mathrm{ml}$, $3.35 \mu \mathrm{g} / \mathrm{ml}$ and $1.92 \mu \mathrm{g} / \mathrm{ml}$, respectively. The $\mathrm{IC}_{50}$ and $\mathrm{IC}_{25}$ values were sharply reduced when the drug treatment time prolonged. These data suggested that $\mathrm{ODA}_{10}\left[\left(\mathrm{PW}_{11} \mathrm{Fe}\right)_{2}\right]$ could inhibit MCF-7 and A549 cells growth in a timedependent manner, and the antiproliferation effect on A549 cells was stronger than that on MCF-7 cells.
Moreover, the antitumor activity of $\mathrm{ODA}_{10}\left[\left(\mathrm{PW}_{11} \mathrm{Fe}\right)_{2}\right]$ was compared with that of dimeric (TEA $)_{10}\left[\left(\mathrm{PW}_{11} \mathrm{FeO}_{39}\right)_{2} \mathrm{O}\right]$. $3 \mathrm{H}_{2} \mathrm{O}$ (abbreviated as TEA) and (TMA) $)_{10}\left[\left(\mathrm{PW}_{11} \mathrm{FeO}_{39}\right)_{2} \mathrm{O}\right]$. $4 \mathrm{H}_{2} \mathrm{O}$ (abbreviated as TMA) containing relatively short alkyl chain at the same concentration, which was shown in Figures 2C,D. After treatment of the drugs for $24 \mathrm{~h}, \mathrm{ODA}_{10}$ $\left[\left(\mathrm{PW}_{11} \mathrm{Fe}\right)_{2}\right]$ showed the highest anticancer effect, while nearly no inhibition efficacy against MCF-7 and A549 cells was induced by TEA and TMA, that is because the longer alkyl chain in the quaternary ammonium cation of $\mathrm{ODA}_{10}$ $\left[\left(\mathrm{PW}_{11} \mathrm{Fe}\right)_{2}\right]$ possessed better cell membrane penetration (Abel et al., 2002), which is beneficial for ODA 10 $\left[\left(\mathrm{PW}_{11} \mathrm{Fe}\right)_{2}\right]$ to interact with tumor cells, thus $\mathrm{ODA}_{10}$ $\left[\left(\mathrm{PW}_{11} \mathrm{Fe}\right)_{2}\right]$ exhibited excellent antiproliferation effect on MCF-7 and A549 cells. The above results demonstrated that the dimeric Keggin-type POMs modified by quaternary ammonium cation with longer alkyl chain showed higher antitumor activity.

The anticancer activity of $\mathrm{ODA}_{10}\left[\left(\mathrm{PW}_{11} \mathrm{Fe}\right)_{2}\right]$ on MCF-7 and A549 cells was further compared with that of the clinical chemotherapeutic agents, such as cisplatin and carboplatin, under the same conditions, which was presented in Figure 3. After treatment of the drugs for $24 \mathrm{~h}, \mathrm{ODA}_{10}\left[\left(\mathrm{PW}_{11} \mathrm{Fe}\right)_{2}\right]$ showed the strongest inhibitory effects against MCF-7 and A549 cells compared to cisplatin and carboplatin. From the above results, it can be demonstrated that $\mathrm{ODA}_{10}$ $\left[\left(\mathrm{PW}_{11} \mathrm{Fe}\right)_{2}\right]$ exhibited an anti-proliferation effect on the tumor cells in a dose- and time-dependent manner, and can be utilized as an antitumor drug candidate for the treatment of cancer. 

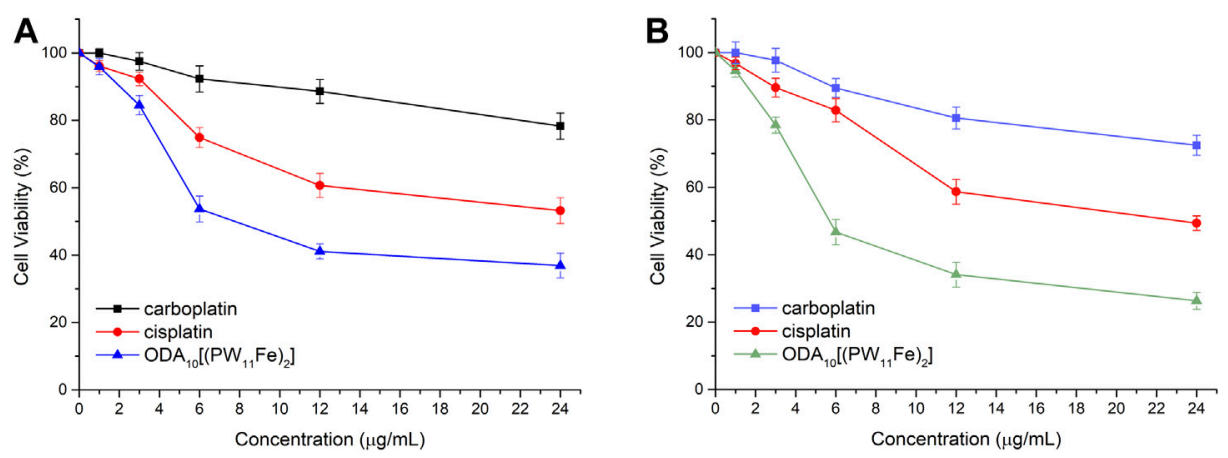

FIGURE 3 | In vitro cytotoxicity profiles of different drugs on MCF-7 cells (A) and A549 cells (B) for 24 h.

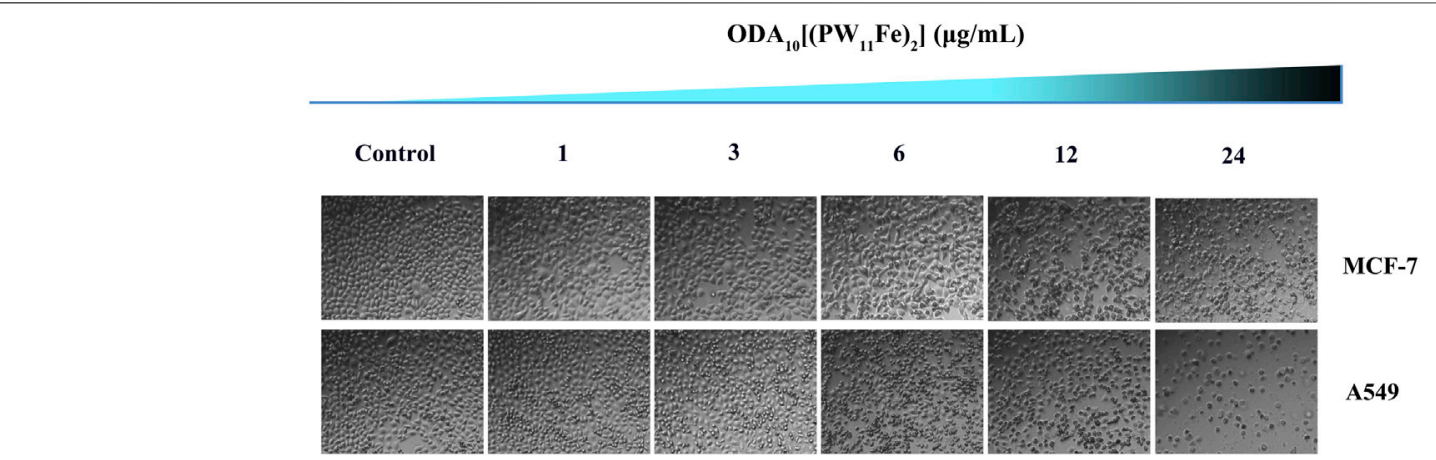

FIGURE 4 | Morphological changes of MCF-7 and A549 cells induced by different concentration of ODA $\mathrm{O}_{10}\left[\left(\mathrm{PW} \mathrm{F}_{11} \mathrm{Fe}\right)_{2}\right]$ for $24 \mathrm{~h}$

\section{Cell Morphology}

The changes of the cellular density and morphology of MCF-7 and A549 cells with the treatment of different doses of $\mathrm{ODA}_{10}$ $\left[\left(\mathrm{PW}_{11} \mathrm{Fe}\right)_{2}\right]$ were directly detected using an inverted microscope (Figure 4). After treatment of $24 \mathrm{~h}$, cells of control group were nested distribution, flattened and showed normal cell architecture. The cell shape was regular polygon and few round cells existed. While the morphology of the $\mathrm{ODA}_{10}$ $\left[\left(\mathrm{PW}_{11} \mathrm{Fe}\right)_{2}\right]$-treated cells obviously changed. The cells were becoming round, shrunken, altered adherence, as well as the appearance of a large number of cell membrane blistering, which was the characteristic morphology of apoptosis. Moreover, the density of the cells was reduced with the drug concentration increasing, showing a dose-dependent effect. This phenomenon indicated that $\mathrm{ODA}_{10}\left[\left(\mathrm{PW}_{11} \mathrm{Fe}\right)_{2}\right]$ could induce cell apoptosis.

\section{Flow Cytometry Analysis of Cell Apoptosis}

The cell apoptosis against MCF-7 and A549 cells induced by different concentrations of $\mathrm{ODA}_{10}\left[\left(\mathrm{PW}_{11} \mathrm{Fe}\right)_{2}\right](1,3,6,12,24 \mu \mathrm{g} /$ $\mathrm{ml}$ ) for $24 \mathrm{~h}$ was evaluated using Annexin V-FITC/PI doublestaining technique. As shown in Figure 5, the apoptotic cells could be obviously detected by distinct double staining patterns: necrotic (upper left square), viable cells (lower left square), late apoptotic (upper right square) and early apoptotic (lower right square). The results manifested that the ratio of apoptotic (early and late) cells induced by $\mathrm{ODA}_{10}\left[\left(\mathrm{PW}_{11} \mathrm{Fe}\right)_{2}\right]$ obviously increased in a dose-dependent manner compared to control group. For MCF-7 cells, after treated with $\mathrm{ODA}_{10}\left[\left(\mathrm{PW}_{11} \mathrm{Fe}\right)_{2}\right]$, the proportion of apoptotic cells ranged from 3.69 to $20.78 \%$ with the concentration increasing, which was higher than that in control group (2.31\%). For A549 cells, the percentage of apoptotic cells in control group was $1.1 \%$, while that in drugtreatment group was $7.88,15.22,27.98,29.68$ and $38.26 \%$ at the concentration of $1-24 \mu \mathrm{g} / \mathrm{ml}$, respectively. Taken together, $\mathrm{ODA}_{10}\left[\left(\mathrm{PW}_{11} \mathrm{Fe}\right)_{2}\right]$ could inhibit the MCF-7 and A549 cells growth and induce the apoptosis of tumor cells.

\section{Flow Cytometry Analysis of Cell Cycle Distribution}

In order to detect whether the antiproliferation effect against MCF-7 and A549 cells of $\mathrm{ODA}_{10}\left[\left(\mathrm{PW}_{11} \mathrm{Fe}\right)_{2}\right]$ is caused by cell cycle arrest, MCF-7 and A549 cells were treated with different 


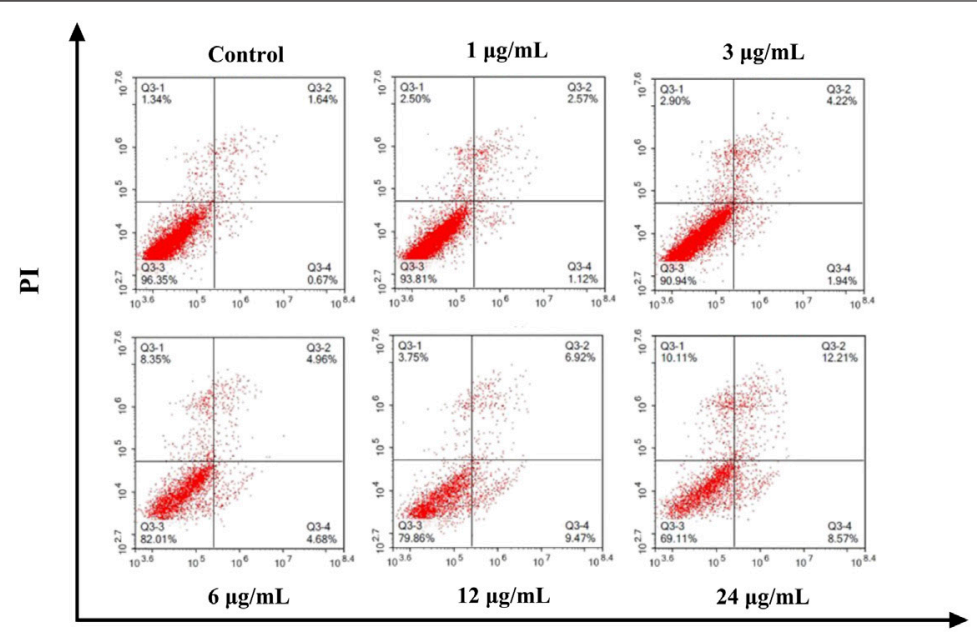

MCF-7

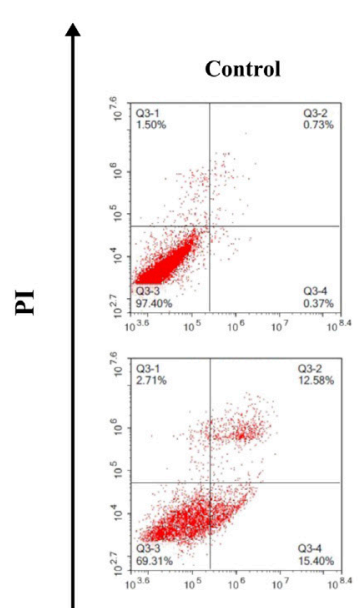

$6 \mu \mathrm{g} / \mathrm{mL}$
Annexin V
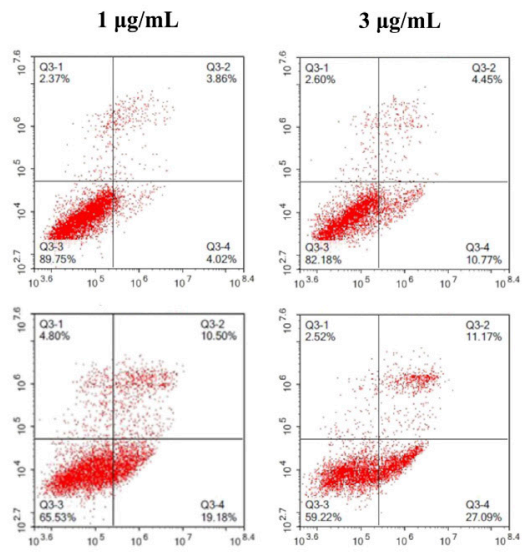

$12 \mu \mathrm{g} / \mathrm{mL}$

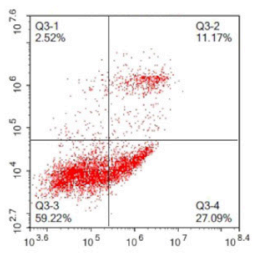

$24 \mu \mathrm{g} / \mathrm{mL}$

Annexin V

FIGURE 5 | Flow cytometry analysis of MCF-7 and A549 cell apoptosis induced by different concentration of $\mathrm{ODA}_{10}\left[\left(\mathrm{PW}{ }_{11} \mathrm{Fe}\right)_{2}\right]$ for $24 \mathrm{~h}$.

doses of $\mathrm{ODA}_{10}\left[\left(\mathrm{PW}_{11} \mathrm{Fe}\right)_{2}\right](1,3,6,12,24 \mu \mathrm{g} / \mathrm{ml})$ for $24 \mathrm{~h}$ with PI staining. The content of DNA was examined by flow cytometry. Generally, the process of cell replication is related to the doubling of DNA and other cellular contents. There are four distinct phases divided from cell cycle distribution: $G_{1}, S, G_{2}$ and $M$ phase, the entry to which is carefully regulated by different checkpoints. $S$ phase is responsible for the synthesis of DNA. The cell prepares to divide during $G_{2}$ phase and division takes place during $M$ phase. Then, the cells continue to divide after passing these checkpoints. Moreover, many external factors such as drugs, radiation and ROS (reactive oxygen species) can induce DNAdamage during $\mathrm{S}$ which causes the death of cells (RodriguezVargas et al., 2012; Preya et al., 2017).

The results of cell cycle arrest of MCF-7 and A549 cells induced by different concentrations of $\mathrm{ODA}_{10}\left[\left(\mathrm{PW}_{11} \mathrm{Fe}\right)_{2}\right]$ from 1 to $24 \mu \mathrm{g} / \mathrm{ml}$ are shown in Figure 6. The cell population at $S$ phase of MCF-7 cells in the drug-treatment group increased from 17.82 to $32.92 \%$, in a dose-dependent effect, which was higher than that in control group (17.71\%). The level of $\mathrm{G}_{2} / \mathrm{M}$ phase exhibited no obvious variations after treatment of $\mathrm{ODA}_{10}$ $\left[\left(\mathrm{PW}_{11} \mathrm{Fe}\right)_{2}\right]$, accompanied by a significant reduction in $\mathrm{G}_{1}$ phase (Figure 6A). Similar to MCF-7 cells, as shown in Figure 6B, for A549 cells, the level of S phase increased from 13.8\% in the control group to $16.89,18.47,36.63,44.39$, and $45.51 \%$, respectively, with the proportions of $G_{1}$ and $G_{2} / M$ phase decreasing. The ratios of $G_{1}$ and $\mathrm{G}_{2} / \mathrm{M}$ phase decreased from 55.74 to $26.7 \%$ and 33.08 to $24.19 \%$, respectively. Since DNA replicates during $S$ phase, the above results manifested that DNA damaged at $S$ phase and the antitumor mechanism on MCF-7 and A549 cells was S phase arrest.

\section{CONCLUSION}

A novel dimeric Keggin-type polyoxometalate (ODA) 10 $\left[\left(\mathrm{PW}_{11} \mathrm{FeO}_{39}\right)_{2} \mathrm{O}\right] \cdot 9 \mathrm{H}_{2} \mathrm{O} \quad\left(\mathrm{ODA}_{10}\left[\left(\mathrm{PW}_{11} \mathrm{Fe}\right)_{2}\right]\right)$ was firstly 

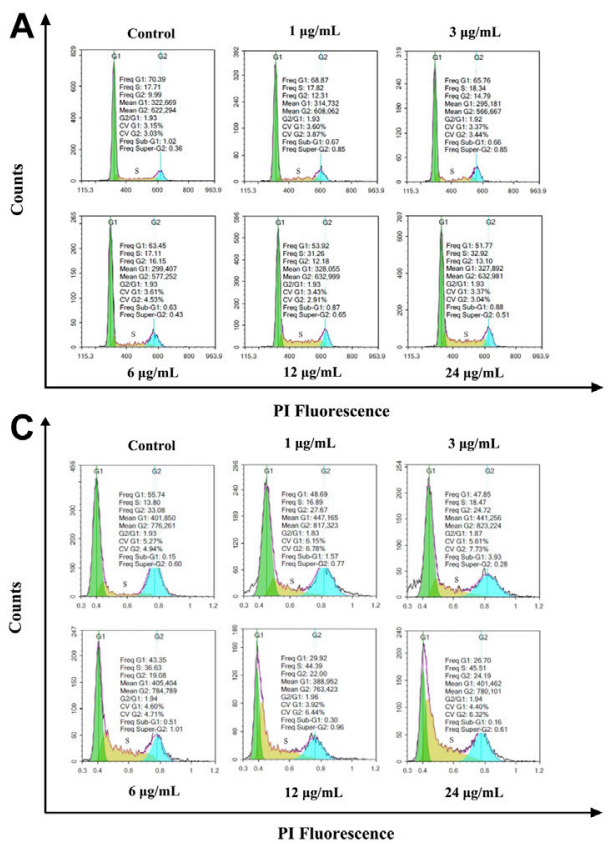

B

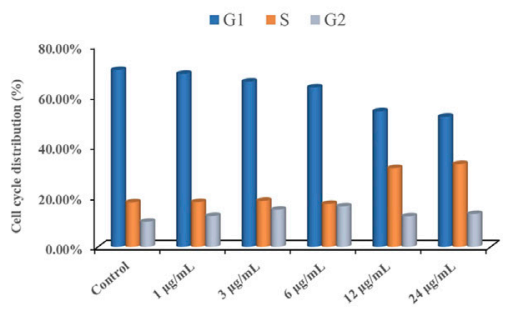

D

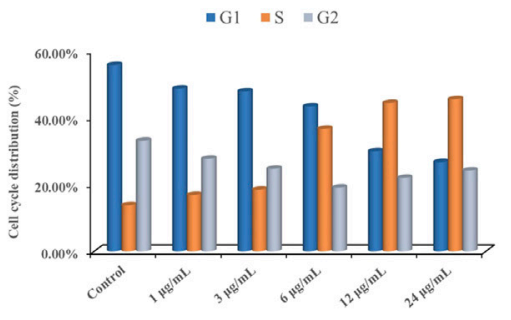

FIGURE 6 | ODA 10 [(PW 11 Fe $\left.)_{2}\right]$ induces cell cycle arrest in MCF-7 and A549 cells. MCF-7 cells (A) and A549 cells (C) were treated with various concentrations of $\mathrm{ODA}_{10}\left[\left(\mathrm{PW}_{11} \mathrm{Fe}\right)_{2}\right]$ for $24 \mathrm{~h}$, and cell cycle arrest was examined by flow cytometry. Quantitative bar graphs of the proportion of MCF-7 cells (B) and A549 cells (D) in different phases.

synthesized with the aid of octadecyltrimethylammonium cation. A comprehensive study on antitumor activity of $\mathrm{ODA}_{10}\left[\left(\mathrm{PW}_{11} \mathrm{Fe}\right)_{2}\right]$ against MCF-7 and A549 cells was carried out. $\mathrm{ODA}_{10}\left[\left(\mathrm{PW}_{11} \mathrm{Fe}\right)_{2}\right]$ could inhibit MCF-7 and A549 cells growth in a dose- and time-dependent manner, and the $\mathrm{IC}_{50}$ value for MCF-7 and A549 cells was $5.83 \mu \mathrm{g} / \mathrm{ml}$ and $3.23 \mu \mathrm{g} / \mathrm{ml}$ at $48 \mathrm{~h}$, respectively. The higher antitumor activity was due to the better cell membrane penetration of octadecyltrimethylammonium cation with longer alkyl chain. The morphology of MCF-7 and A549 cells treated with $\mathrm{ODA}_{10}\left[\left(\mathrm{PW}_{11} \mathrm{Fe}\right)_{2}\right]$ exhibited the characteristics of apoptosis. The Flow cytometry analysis results manifested the fact of the cell apoptosis and cycle arrested at $S$ phase induced by $\mathrm{ODA}_{10}\left[\left(\mathrm{PW}_{11} \mathrm{Fe}\right)_{2}\right]$ as the main mechanism for antiproliferation of MCF-7 and A549 cells. Our work has demonstrated that $\mathrm{ODA}_{10}\left[\left(\mathrm{PW}_{11} \mathrm{Fe}\right)_{2}\right]$ can be utilized as an antitumor drug candidate for the treatment of cancer.

\section{REFERENCES}

Abel, T., Cohen, J. I., Engel, R., Filshtinskaya, M., Melkonian, A., and Melkonian, K. (2002). Preparation and investigation of antibacterial carbohydrate-based surfaces. Carbohydr. Res. 337, 2495-2499. doi:10.1016/S0008-6215(02)00316-6

Arkenau, H. T., Bermann, A., Rettig, K., Strohmeyer, G., and Porschen, R. (2003). 5-Fluorouracil plus leucovorin is an effective adjuvant chemotherapy in curatively resected stage III colon cancer: long-term follow-up results of the adjCCA-01 trial. Ann. Oncol. 14, 395-399. doi:10.1093/annonc/mdg100

Bijelic, A., Aureliano, M., and Rompel, A. (2019). Polyoxometalates as potential next-generation metallodrugs in the combat against cancer. Angew. Chem. Int. Ed. Engl. 58, 2980-2999. doi:10.1002/anie.201803868

\section{DATA AVAILABILITY STATEMENT}

The original contributions presented in the study are included in the article/Supplementary Material, further inquiries can be directed to the corresponding author.

\section{AUTHOR CONTRIBUTIONS}

YX and WL designed the experiments. YY, MC, and JG carried out the experiments and wrote the manuscript. GC and HL helped analyzing the experimental results.

\section{FUNDING}

This work was financially supported by the Grant of Jilin Province Science \& Technology Committee (No. 20180101194JC).

Boulmier, A., Feng, X. X., Oms, O., Mialane, P., Rivière, E., Shin, C. J., et al. (2017). Anticancer activity of polyoxometalate-bisphosphonate complexes: synthesis, characterization, in vitro and in vivo results. Inorg. Chem. 56, 7558-7565. doi:10.1021/acs.inorgchem.7b01114

Cao, H., Li, C., Qi, W., Meng, X., Tian, R., Qi, Y., et al. (2017). Synthesis, cytotoxicity and antitumour mechanism investigations of polyoxometalate doped silica nanospheres on breast cancer MCF-7 cells. PLoS One. 12, e0181018. doi:10.1371/journal.pone.0181018

Cao, S. W., Lin, C. H., Liang, S. N., Chee, H. T., Phei, E. S., and Xu, X. D. (2020). Enhancing chemotherapy by RNA interference. BIO Integration. 1 (18), 64-81. doi:10.15212/bioi-2020-0003

Carr, C., Ng, J., and Wigmore, T. (2008). The side effects of chemotherapeutic agents. Curr. Anaesth. Crit. Care. 19, 70-79. doi:10.1016/j.cacc.2008. 01.004 
Chen, Q., Yang, Y., Lin, X., Ma, W., Chen, G., Li, W., et al. (2018). Platinum(iv) prodrugs with long lipid chains for drug delivery and overcoming cisplatin resistance. Chem. Commun. 54, 5369-5372. doi:10.1039/c8cc02791a

Chen, Y. H., Du, M., Yu, J. S., Rao, L., Chen, X. Y., and Chen, Z. Y. (2020). Nanobiohybrids: a synergistic integration of bacteria and nanomaterials in cancer therapy. BIO Integration. 1 (12), 25-36. doi:10.15212/bioi-2020-0008

Cheng, M., Li, N., Wang, N., Hu, K. H., Xiao, Z. C., Wu, P. F., et al. (2018). Synthesis, structure and antitumor studies of a novel decavanadate complex with a wavelike two-dimensional network. Polyhedron. 155, 313-319. doi:10. 1016/j.poly.2018.08.052

Dianat, S., Bordbar, A. K., Tangestaninejad, S., Yadollahi, B., Amiri, R., ZarkeshEsfahani, S. H., et al. (2015). In vitro antitumor activity of free and nanoencapsulated $\mathrm{Na}_{5}\left[\mathrm{PMo}_{10} \mathrm{~V}_{2} \mathrm{O}_{40}\right] \cdot \mathrm{nH}_{2} \mathrm{O}$ and its binding properties with ctDNA by using combined spectroscopic methods. J. Inorg. Biochem. 152, 74-81. doi:10.1016/j.jinorgbio.2015.08.015

Dianat, S., Bordbar, A. K., Tangestaninejad, S., Yadollahi, B., Zarkesh-Esfahani, S. H., and Habibi, P. (2013). ctDNA binding affinity and in vitro antitumor activity of three Keggin type polyoxotungestates. J. Photochem. Photobiol. B. 124, 27-33. doi:10.1016/j.jphotobiol.2013.04.001

Diz, M., Infante, M. R., and Erra, P. (2001). Antimicrobial activity of wool treated with a new thiol cationic surfactant. Text. Res. J. 71, 695-700. doi:10.1177/ 004051750107100808

Dizman, B., Elasri, M. O., and Mathias, L. J. (2006). Synthesis and antibacterial activities of water-soluble ethacrylate polymers containing quaternary ammonium compounds. J. Polym. Sci. Part A: Polym. Chem. 44, 5965-5973. doi:10.1002/pola.21678

Du, D. Y., Qin, J. S., Li, S. L., Lan, Y. Q., Wang, X. L., and Su, Z. M. (2010). 3d-4f heterometallic complexes for the construction of POM-based inorganic-organic hybrid compounds: from nanoclusters to one-dimensional ladder-like chains. Aust. J. Chem. 63, 1389-1395. doi:10.1071/CH10047

Geraldi, A. (2020). Advances in the production of minor ginsenosides using microorganisms and their enzymes. BIO Integration. 1, 15-24. doi:10.15212/ bioi-2020-0007

Goura, J., Bassil, B. S., Bindra, J. K., Rutkowska, I. A., Kulesza, P. J., Dalal, N. S., et al. (2020). Fe III $^{\text {III }}$-containing 96-tungsto-16-phosphate: synthesis, structure, magnetism and electrochemistry. Chem. Eur. J. 26, 1-5. doi:10.1002/chem. 202002832

Guo, Z. J., and Sadler, P. J. (1999). Medicinal inorganic chemistry. Adv. Inorg. Chem. 49, 183-306. doi:10.1016/S0898-8838(08)60271-8

Hamis, S., Nithiarasu, P., and Powathil, G. G. (2018). What does not kill a tumour may make it stronger: in silico insights into chemotherapeutic drug resistance. J. Theor. Biol. 454, 253-267. doi:10.1016/j.jtbi.2018.06.014

Hill, C. L. (2007). Progress and challenges in polyoxometalate-based catalysis and catalytic materials chemistry. J. Mol. Catal. A Chem. 262, 2-6. doi:10.1016/j. molcata.2006.08.042

Hu, X. K., Wang, H., Huang, B., Li, N., Hu, K. H., Wu, B. L., et al. (2019). A new scheme for rational design and synthesis of polyoxovanadate hybrids with high antitumor activities. J. Inorg. Biochem. 193, 130-132. doi:10.1016/j.jinorgbio. 2019.01.013

Jalil, P. A., Faiz, M., Tabet, N., Hamdan, N. M., and Hussain, Z. (2003). A study of the stability of tungstophosphoric acid, $\mathrm{H}_{3} \mathrm{PW}_{12} \mathrm{O}_{40}$, using synchrotron XPS, XANES, hexane cracking, XRD, and IR spectroscopy. J. Catal. 217, 292-297. doi:10.1016/S0021-9517(03)00066-6

Jasmin, C., Chermann, J., Herve, G., Teze, A., Souchay, P., Boy-Loustau, C., et al. (1974). In vivo inhibition of murine leukemia and sarcoma viruses by the heteropolyanion 5-tungsto-2-antimoniate. J. Natl. Cancer. I 53, 469-474. doi:10.1093/jnci/53.2.469

Jonckheere, N., Skrypek, N., and Van Seuningen, I. (2014). Mucins and tumor resistance to chemotherapeutic drugs. Biochim. Biophys. Acta. 1846, 142-151. doi:10.1016/j.bbcan.2014.04.008

Judd, D. A., Nettles, J. H., Nevins, N., Snyder, J. P., Liotta, D. C., Tang, J., et al. (2001). Polyoxometalate HIV-1 protease inhibitors. A new mode of protease inhibition. J. Am. Chem. Soc. 123, 886-897. doi:10.1021/ja001809e

Kurtz, D. M., Jr (1990). Oxo- and hydroxo-bridged diiron complexes: a chemical perspective on a biological unit. Chem. Rev. 90, 585-606. doi:10.1021/ cr00102a002

Kuznetsova, L. I., Detusheva, L. G., Fedotov, M. A., and Likholobov, V. A. (1996). Catalytic properties of heteropoly complexes containing Fe(III) ions in benzene oxidation by hydrogen peroxide. J. Mol. Catal. A Chem. 111, 81-90. doi:10. 1016/1381-1169(96)00207-5

Kuznetsova, L. I., Detusheva, L. G., Kuznetsova, N. I., Fedotov, M. A., and Likholobov, V. A. (1997). Relation between structure and catalytic properties of transition metal complexes with heteropolyanion $\mathrm{PW}_{11} \mathrm{O}_{39}{ }^{7-}$ in oxidative reactions. J. Mol. Catal. A Chem. 117, 389-396. doi:10.1016/S13811169(96)00294-4

Li, C. Y., Cao, H. Q., Sun, J. H., Tian, R., Li, D. B., Qi, Y. F., et al. (2017). Antileukemic activity of an arsenomolybdate in the human HL-60 and U937 leukemia cells. J. Inorg. Biochem. 168, 67-75. doi:10.1016/j.jinorgbio.2016. 12.002

Liu, J., Xu, M. Z., and Yuan, Z. (2020). Immunoscore guided cold tumors to acquire "temperature" through integrating physicochemical and biological methods. BIO Integration. 1, 6-14. doi:10.15212/bioi-2020-0002

Liu, K., Xu, Y. Q., Yao, Z. X., Miras, H. N., and Song, Y. F. (2016). Polyoxometalateintercalated layered double hydroxides as efficient and recyclable bifunctional catalysts for cascade reactions. ChemCatChem. 8, 929-937. doi:10.1002/cctc. 201501365

Liu, W. J., Al-Oweini, R., Meadows, K., Bassil, B. S., Lin, Z. G., Christian, J. H., et al. (2016). $\mathrm{Cr}^{\mathrm{III}}$-substituted heteropoly-16-tungstates $\left[\mathrm{Cr}_{2}^{\mathrm{III}}\left(B-\beta-\mathrm{X}^{\mathrm{IV}} \mathrm{W}_{8} \mathrm{O}_{31}\right)_{2}\right]^{14-}$ $(\mathrm{X}=\mathrm{Si}, \mathrm{Ge})$ : magnetic, biological, and electrochemical studies. Inorg. Chem. 55 , 10936-10946. doi:10.1021/acs.inorgchem.6b01458

Liu, X., Gan, Q., and Feng, C. G. (2016). Synthesis, characterization and biological activity of 5-fluorouracil derivatives of rare earth (Gd, Dy, Er) substituted phosphotungstate. Inorg. Chim. Acta. 450, 299-303. doi:10.1016/j.ica.2015. 11.034

Ma, T., Yang, P., Dammann, I., Lin, Z. G., Mougharbel, A. S., Li, M. X., et al. (2020). Tetra-( $p$-tolyl)antimony(III)-containing heteropolytungstates, [\{( $p$-tolyl) $\left.\left.\mathrm{Sb}^{\mathrm{III}}\right\}_{4}\left(\mathrm{~A}-\alpha-\mathrm{XW}_{9} \mathrm{O}_{34}\right)_{2}\right]^{\mathrm{n}-}(\mathrm{X}=\mathrm{P}, \mathrm{As}$, or $\mathrm{Ge})$ : synthesis, structure, and study of antibacterial and antitumor activity. Inorg. Chem. 59, 2978-2987. doi:10. 1021/acs.inorgchem.9b03322

Mathias, L., Almeida, J., Passoni, L., Gossani, C., Taveira, G., Gomes, V., et al. (2020). Antifungal activity of silver salts of Keggin-type heteropolyacids against sporothrix spp. J. Microbiol. Biotechnol. 30, 540-551. doi:10.4014/jmb.1907. 07064

Mizuno, N., Yamaguchi, K., and Kamata, K. (2005). Epoxidation of olefins with hydrogen peroxide catalyzed by polyoxometalates. Coordin. Chem. Rev. 249, 1944-1956. doi:10.1016/j.ccr.2004.11.019

Muller, A., Peters, F., Pope, M. T., and Gatteschi, D. (1998). Polyoxometalates: very large clusters-nanoscale magnets. Chem. Rev. 98, 239-271. doi:10.1021/ cr9603946

Müller, C. E., Iqbal, J., Baqi, Y., Zimmermann, H., Röllich, A., and Stephan, H. (2006). Polyoxometalates-a new class of potent ecto-nucleoside triphosphate diphosphohydrolase (NTPDase) inhibitors. Bioorg. Med. Chem. Lett. 16, 5943-5947. doi:10.1016/j.bmcl.2006.09.003

Myrzakozha, D. A., Hasegawa, T., Nishijo, J., Imae, T., and Ozaki, Y. (1999a). An infrared study of molecular orientation and structure in one-layer langmuir-blodgett films of octadecyldimethylamine oxide and dioctadecyldimethylammonium chloride: dependence of the structures of the langmuir-blodgett films on substrates, aging, and $\mathrm{pH}$ of water subphase. Langmuir. 15, 6890-6896. doi:10.1021/la9806294

Myrzakozha, D. A., Hasegawa, T., Nishijo, J., Imae, T., and Ozaki, Y. (1999b). Structural characterization of langmuir-blodgett films of octadecyldimethylamine oxide and dioctadecyldimethylammonium chloride. 2. thickness dependence of thermal behavior investigated by infrared spectroscopy and wetting measurements. Langmuir. 15, 3601-3607. doi:10.1021/la981016u

Pichon, C., Dolbecq, A., Mialane, P., Marrot, J., Rivière, E., Goral, M., et al. (2008). $\mathrm{Fe}_{2}$ and $\mathrm{Fe}_{4}$ clusters encapsulated in vacant polyoxotungstates: hydrothermal synthesis, magnetic and electrochemical properties, and DFT calculations. Chem. Eur. J. 14, 3189-3199. doi:10.1002/chem.200700896

Preya, U. H., Lee, K. T., Kim, N. J., Lee, J. Y., Jang, D. S., and Choi, J. H. (2017). The natural terthiophene alpha-terthienylmethanol induces $S$ phase cell cycle arrest of human ovarian cancer cells via the generation of ROS stress. Chem. Biol. Interact. 272, 72-79. doi:10.1016/j.cbi.2017.05.011

Prudent, R., Moucadel, V., Laudet, B., Barette, C., Lafanechère, L., Hasenknopf, B., et al. (2008). Identification of polyoxometalates as nanomolar noncompetitive inhibitors of protein kinase CK2, Chem. Biol. 15, 683-692. doi:10.1016/j. chembiol.2008.05.018 
Qi, Y., Xiang, Y., Wang, J., Qi, Y., Li, J., Niu, J., et al. (2013). Inhibition of hepatitis C virus infection by polyoxometalates. Antiviral. Res. 100, 392-398. doi:10.1016/j. antiviral.2013.08.025

Qu, X. S., Feng, H., Ma, C., Yang, Y. Y., and Yu, X. Y. (2017). Synthesis, crystal structure and anti-tumor activity of a novel 3D supramolecular compound constructed from Strandberg-type polyoxometalate and benzimidazole. Inorg. Chem. Commun. 81, 22-26. doi:10.1016/j.inoche.2017.04.023

Rhule, J. T., Hill, C. L., Judd, D. A., and Schinazi, R. F. (1998). Polyoxometalate in medicine. Chem. Rev. 98, 327-358. doi:10.1021/cr960396q

Rodriguez-Vargas, J. M., Ruiz-Magana, M. J., Ruiz-Ruiz, C., Majuelos-Melguizo, J., Peralta-Leal, A., Rodriguez, M. I., et al. (2012). ROS-induced DNA damage and PARP-1 are required for optimal induction of starvation-induced autophagy. Cell. Res. 22, 1181-1198. doi:10.1038/cr.2012.70

Santos, F. M., Brandão, P., Félix, V., Domingues, M. R. M., Amaral, J. S., Amaral, V., et al. (2012). Organic-inorganic hybrid materials based on iron(III)polyoxotungstates and 1-butyl-3-methylimidazolium cations. Dalton. Trans. 41, 12145-12155. doi:10.1039/C2DT31206A

Shigeta, S., Mori, S., Kodama, E., Kodamaa, J., Takahashi, K., and Yamase, T. (2003). Broad spectrum anti-RNA virus activities of titanium and vanadium substituted polyoxotungstates. Antiviral. Res. 58, 265-271. doi:10.1016/S0166-3542(03)00009-3

Ssif, M. W., Katirtzoglou, N. A., and Syrigos, K. N. (2008). Capecitabine: an overview of the side effects and their management. Anticancer Drugs. 19, 447-464. doi:10.1097/CAD.0b013e3282f945aa

Sun, T. D., Cui, W., Yan, M., Qin, G., Guo, W., Gu, H. X., et al. (2016). Target delivery of a novel antitumor organoplatinum(IV)-substituted polyoxometalate complex for safer and more effective colorectal cancer therapy in vivo. Adv. Mater. 28, 7397-7404. doi:10.1002/adma.201601778

Sun, X. F., Wu, Y., Gao, W. D., Enjyoji, K., Csizmadia, E., Müller, C. E., et al. (2010). $\mathrm{CD} 39 / \mathrm{ENTPD} 1$ expression by $\mathrm{CD} 4^{+}$Foxp $3^{+}$regulatory T cells promotes hepatic metastatic tumor growth in mice. Gastroenterology. 139, 1030-1040. doi:10. 1053/j.gastro.2010.05.007

Sun, Y. B., Ma, W., Yang, Y. Y., He, M. X., Li, A. M., Bai, L., et al. (2019). Cancer nanotechnology: enhancing tumor cell response to chemotherapy for hepatocellular carcinoma therapy. Asian. J. Pharm. 14, 581-594. doi:10.1016/j.ajps.2019.04.005

Van Rompuy, L. S., and Parac-Vogt, T. N. (2019). Interactions between polyoxometalates and biological systems: from drug design to artificial enzymes. Curr. Opin. Biotech. 58, 92-99. doi:10.1016/j.copbio.2018.11.013
Wang, X. H., Liu, J. F., and Pope, M. T. (2003). New polyoxometalate/starch nanomaterial: synthesis, characterization and antitumoral activity. Dalton Trans. (5), 957-960. doi:10.1039/B300920N

Weiss, R. B., and Christian, M. C. (1993). New cisplatin analogues in development. A review. Drugs. 46, 360-377. doi:10.2165/00003495-199346030-00003

Xiao, Y. F., An, F. F., Chen, J. X., Yu, J., Yu, Z. Q., Ting, R., et al. (2019). The nanoassembly of an intrinsically cytotoxic near-infrared dye for multifunctionally synergistic theranostics. Small. 15, 1903121. doi:10.1002/ smll.201903121

Yu, H., Le, S. L., Zeng, X. H., Zhang, J. Y., and Xie, J. L. (2014). Facile synthesis of a novel mono-organoimido functionalized polyoxometalate cluster $\left[\left(\mathrm{n}-\mathrm{C}_{4} \mathrm{H}_{9}\right)_{4} \mathrm{~N}\right]_{2}\left[\mathrm{Mo}_{6} \mathrm{O}_{18}(\equiv \mathrm{NAr})\right]\left(\mathrm{Ar}=\mathrm{p}-\mathrm{C}_{2} \mathrm{H}_{5} \mathrm{C}_{6} \mathrm{H}_{4}\right)$ : crystal structure, spectral characterization and initial antitumor activity. Inorg. Chem. Commun. 39, 135-139. doi:10.1016/j.inoche.2013.11.001

Zhao, Z. J., He, Z. H., Huang, H. Y., Chen, J. W., He, S. S., Yilihamu, A., et al. (2020). Drug-induced interstitial lung disease in breast cancer patients: a lesson we should learn from multi-disciplinary integration. BIO Integration. 1 (10), 82-91. doi:10.15212/bioi-2020-0009

Zheng, L., Ma, Y., Zhang, G. J., Yao, J. N., Bassil, B. S., Kortz, U., et al. (2009). Molecular interaction between a gadolinium-polyoxometalate and human serum albumin. Eur. J. Inorg. Chem. 5189-5193. doi:10.1002/ejic. 200900610

Conflict of Interest: Author HL was employed by the company NCPC Hebei Lexin Pharmaceutical Co., Ltd.

The remaining authors declare that the research was conducted in the absence of any commercial or financial relationships that could be construed as a potential conflict of interest.

Copyright (C) 2021 Xue, Yin, Li, Chi, Guo, Cui and Li. This is an open-access article distributed under the terms of the Creative Commons Attribution License (CC BY). The use, distribution or reproduction in other forums is permitted, provided the original author(s) and the copyright owner(s) are credited and that the original publication in this journal is cited, in accordance with accepted academic practice. No use, distribution or reproduction is permitted which does not comply with these terms. 